\title{
Lingual metastasis as an initial presentation of renal cell carcinoma: a case report
}

\author{
Hanan Raiss ${ }^{*}$, Sophie Duplomb², Sophie Tartas ${ }^{2}$, Mohamed Layachi ${ }^{1}$ and Hassan Errihani ${ }^{1}$
}

\begin{abstract}
Background: Renal cell carcinoma is the third most common tumor that metastasizes to the head and neck, after breast and lung carcinomas. Tongue metastasis as an initial presentation of renal cell carcinoma is extremely rare, and very few cases have been reported. The prognosis is poor. We present a rare case of metastatic renal cell carcinoma that initially presented as a tongue lesion.

Case presentation: We report the case of a 55 -year-old white man who presented with a large exophytic lesion on his tongue. A biopsy was taken, and pathologic examination showed a poorly differentiated carcinoma including a sarcomatoid component. Subtotal glossectomy with neck dissection were planned, but a positron emission tomographic-computed tomography scan showed a left kidney mass. Immunohistochemical evaluation of the tongue lesion was performed, and it was compatible with metastasis from primary renal cell carcinoma. The biopsy of the renal lesion showed a high-grade unclassified renal cell carcinoma. Although our patient underwent systemic therapy, he died of hemorrhagic complications 3 months after the initiation of therapy.
\end{abstract}

Conclusion: Tongue lesions require a complete assessment to distinguish a metastasis from a primary cancer in order to give the appropriate treatment.

Keywords: Renal cell carcinoma, Tongue metastasis, Lingual metastasis, Sarcomatoid component

\section{Background}

Lingual metastases are extremely rare, accounting for less than $1 \%$ of all malignant tongue lesions [1]. Renal cell carcinoma (RCC) is the third most common tumor that metastasizes to the head and neck [2]. The most commonly affected organs are the paranasal sinuses, larynx, jaws, temporal bones, thyroid gland, and parotid glands [3]. Very few cases have presented initially as a tongue metastasis before the diagnosis of primary RCC [4]. Proposed mechanisms for RCC metastasis involve the arterial, venous, or lymphatic circulation. Hematogenous spread appears to be the most common mechanism of distant metastases. RCC invades the local vascular network of the kidney, spreading through the systemic circulation. Head and neck metastases are mostly related to lung metastases. In the absence of pulmonary metastases, spread can be explained through Batson's venous plexus. This valveless

\footnotetext{
* Correspondence: raiss.hanan@gmail.com

'Service d'Oncologie Médicale, Institut National d'Oncologie, CHU Rabat and Université Mohamed V, Avenue Allal Al Fassi, Madinat Al Irfane, 10000 Rabat, Morocco

Full list of author information is available at the end of the article
}

system offers little resistance to the spread of tumor emboli, allowing retrograde flow from the abdominal cavity $[1,5]$.

The prognosis of metastatic RCC is poor and 5-year survival is less than 10\% [5]. Treatment of tongue metastases is usually palliative [6], including surgery, radiotherapy, and systemic therapy. Surgical excision may be proposed to provide short-term palliation of the symptoms and patient comfort [2]; this can be followed by adjuvant radiotherapy to achieve local control of the disease [6]. Systemic therapy for patients with metastatic RCC was previously limited to cytokine therapy with high-dose interleukin-2 (IL-2) and interferon-alpha $($ IFN- $\alpha$ ) [7]. In recent years, several new therapies have become available. These include multitarget tyrosine kinase inhibitors (sunitinib, sorafenib, axitinib, pazopanib, cabozantinib, lenvatinib), monoclonal vascular endothelial growth factor (VEGF)-antibody (bevacizumab), mammalian target of rapamycin (mTOR) inhibitors (everolimus and temsirolimus), and immunotherapy (nivolumab). Thanks to these new therapies, the 
prognosis of patients with metastatic RCC has improved considerably [8].

We present a case of metastatic RCC that initially presented as a tongue lesion and we discuss the clinical aspects, the difficulties in diagnosis, and the therapeutic options in light of the recent literature.

\section{Case presentation}

A 55-year-old white man, who was a chronic tobacco smoker, came to our otorhinolaryngology department because of a pedunculated painful lesion on his tongue. He was married and was living with his wife. His medical history included hypertension which is controlled with an angiotensin-converting enzyme inhibitor. On clinical examination, he had a performance status of 1 , his blood pressure was $120 / 70 \mathrm{mmHg}$, temperature was $37.2{ }^{\circ} \mathrm{C}$, and heart rate was 90 beats/minute with negative dipstick. An oral examination showed a large exophytic lesion occupying the anterior two thirds of the right side of his tongue (Fig. 1). Neurological examination, fiber optic nasopharyngoscopy, and laryngoscopy were normal. Complete blood count was normal with a hemoglobin level of $12 \mathrm{~g} / \mathrm{dL}$, a platelet count of $300 \times$

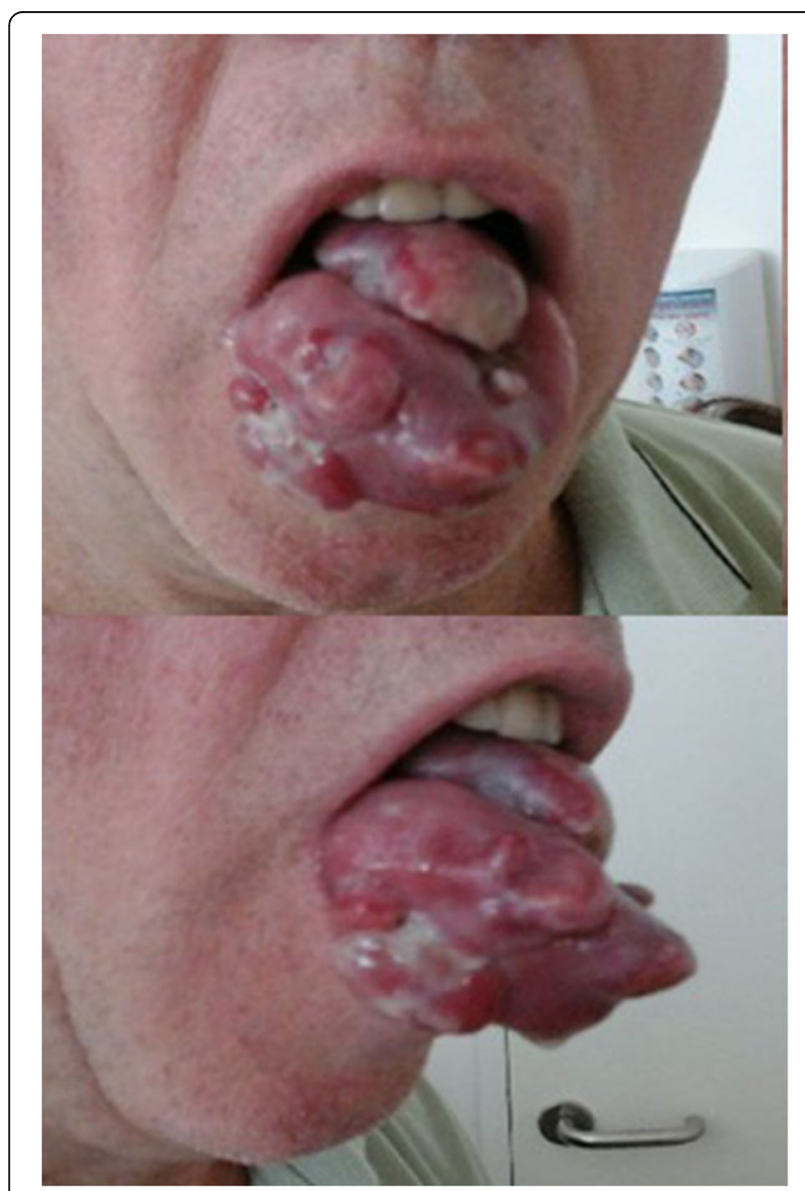

Fig. 1 Tongue lesion before treatment
$10^{9} / \mathrm{L}$, and white cell count of $5 \times 10^{9} / \mathrm{L}$. His renal function was normal with a creatinine of $0.8 \mathrm{mg} / \mathrm{dL}$. His corrected serum calcium was $2.39 \mathrm{mmol} / \mathrm{L}$ and lactate dehydrogenase (LDH) level was $202 \mathrm{UI} / \mathrm{L}$. Aspartate aminotransferase, alanine aminotransferase, and bilirubin were normal. A biopsy of the lesion was taken. Pathologic examination showed a poorly differentiated carcinoma, including a sarcomatoid component represented by spindle cells. Subtotal glossectomy with neck dissection were planned after a staging positron emission tomographic-computed tomography (PET-CT) scan. The PET-CT scan revealed a tongue lesion, bilateral pulmonary metastases, muscle metastases, and a left kidney mass (Figs. 2 and 3). An abdominal computed tomography $(\mathrm{CT})$ scan confirmed the presence of a 13 $\mathrm{cm}$ left kidney mass.

Our patient was referred to our oncology department. A detailed medical history was performed, and he described an episode of macroscopic hematuria. A physical examination revealed a subcutaneous nodule in his right axillary region. He had a performance status of 1 , and arterial pressure was normal. An immunohistochemical evaluation was performed, and it was positive for $\operatorname{Pax} 8$, CD10, and AE1/AE3 and negative for CK20, CK7, and thyroid transcription factor 1 (TTF1). This result is compatible with a metastasis from a primary renal cell cancer. A biopsy of the renal lesion was performed. Morphological and immunohistochemical findings were consistent with a high-grade unclassified RCC.

The tongue lesion doubled in size within 2 weeks. Treatment was initiated with sunitinib $50 \mathrm{mg} / \mathrm{day}$, on a schedule of 4 weeks on treatment followed by 2 weeks off. After 2 weeks of treatment, the size of the tongue lesion as well as the size of a subcutaneous nodule had decreased a little (Fig. 4). Sunitinib treatment was discontinued after one cycle because of an unexplained fever. Subsequently, the mass on our patient's tongue grew and protruded outside his mouth, and caused difficulty in swallowing. CT imaging showed progression of the disease on his tongue, lung, lymph nodes, and muscle. He started second-line systemic therapy with doxorubicin and gemcitabine, but he died 10 days later because of a hemorrhagic complication of the tongue lesion.

\section{Discussion}

RCC is one of the most common tumors to metastasize to the head and neck region, after lung and breast cancer $[2,4,5]$. A tongue metastasis as an initial presentation of RCC is extremely rare $[4,5]$. An exhaustive literature review conducted by Azam et al. showed 28 reported cases of RCC tongue metastases from 1911 to 2008 [5]. Out of these, three cases presented initially with tongue metastases $[3,5]$. To complete this study, we conducted an additional literature review, presented in Table 1, of 18 cases published from 2008 to 2017 [3, 


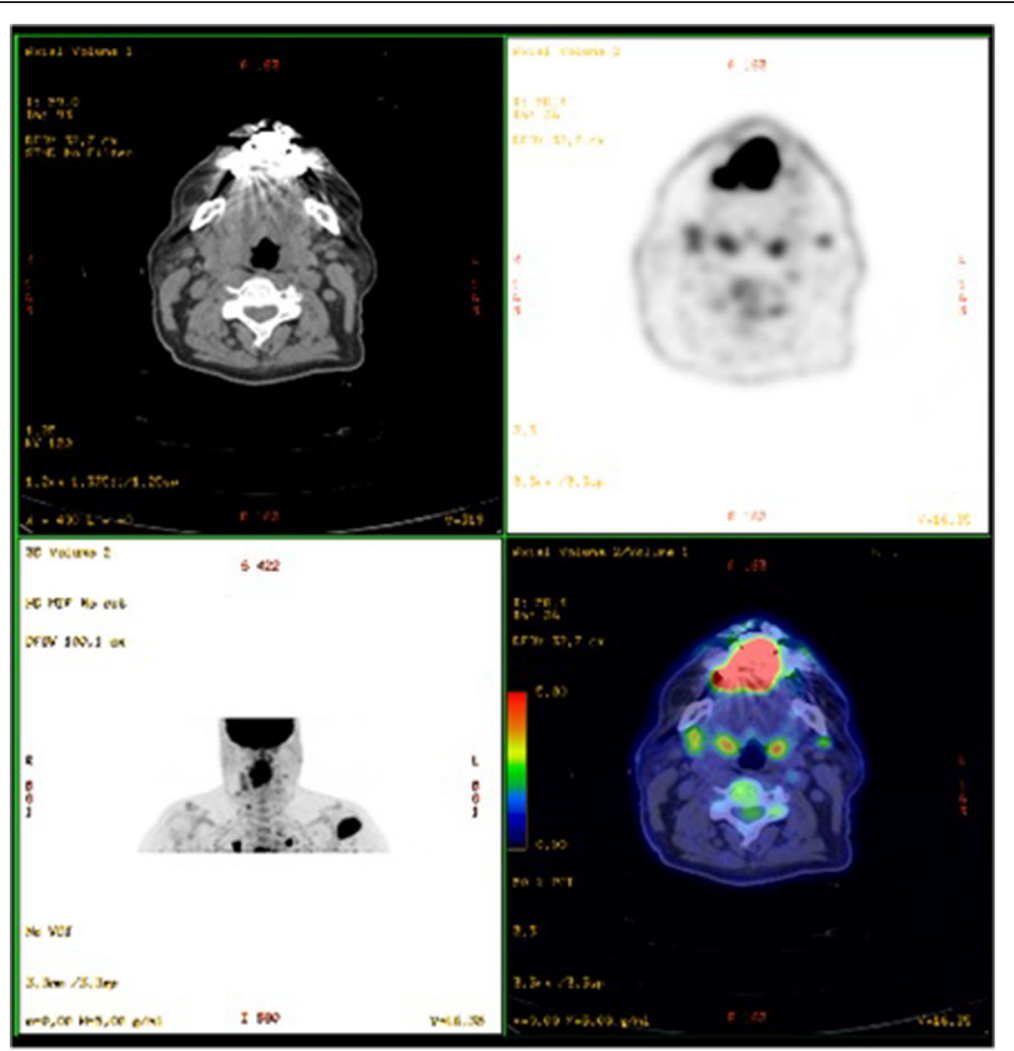

Fig. 2 Positron emission tomographic-computed tomography scan shows a tongue lesion

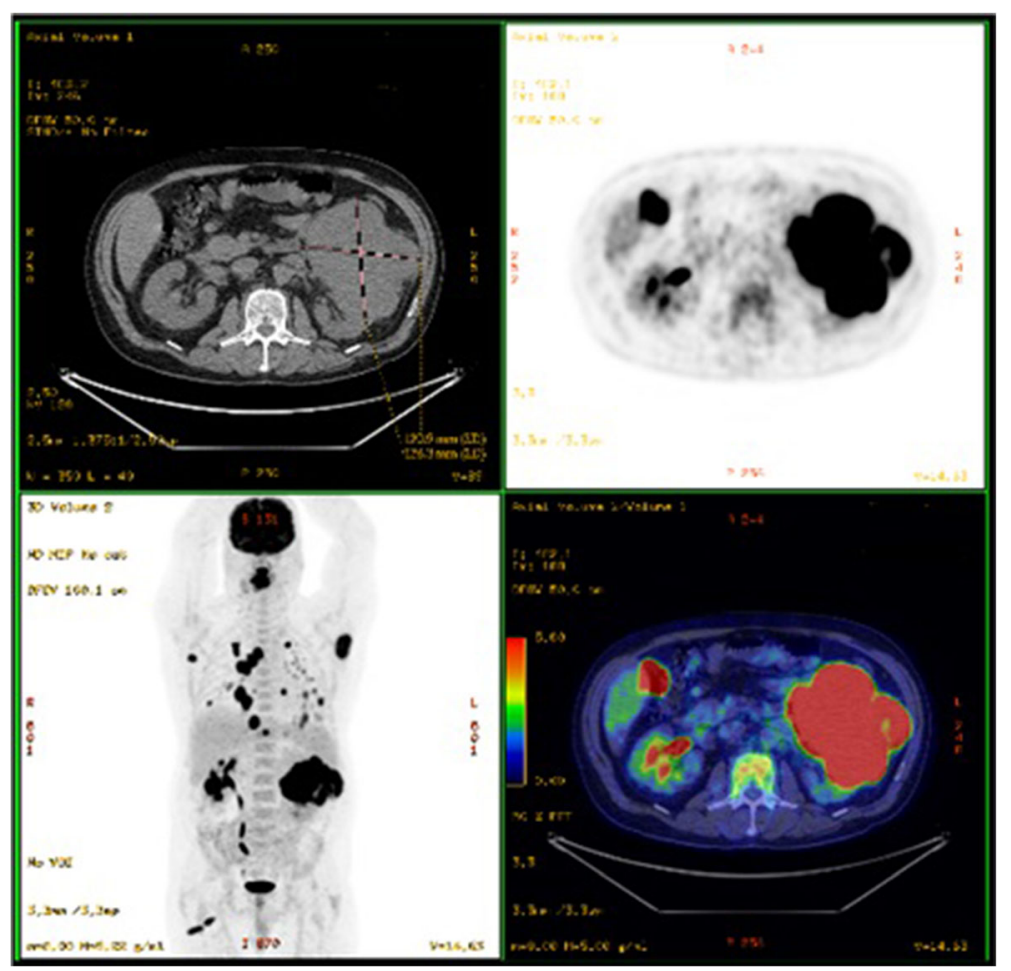

Fig. 3 Positron emission tomographic-computed tomography scan shows a left kidney mass 


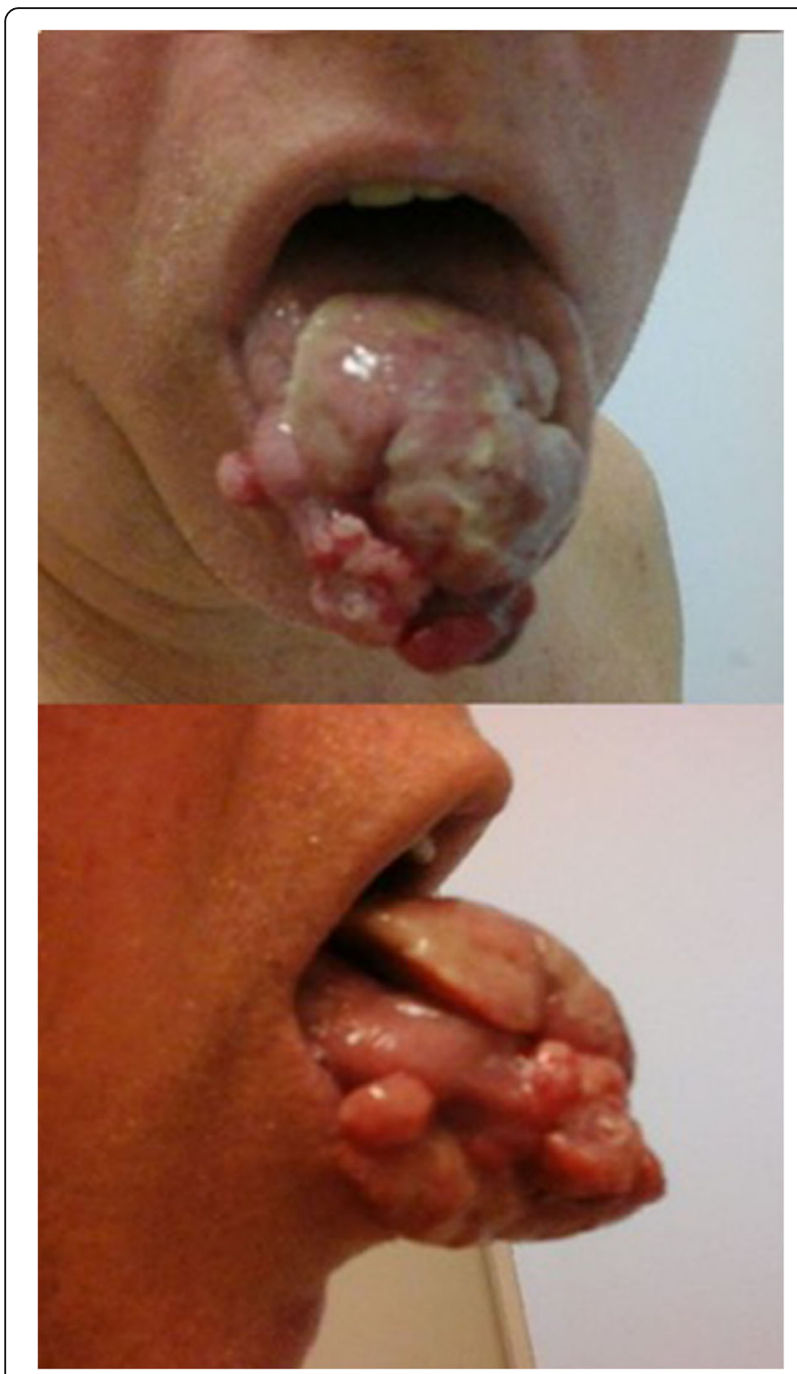

Fig. 4 Tongue lesion after 2 weeks of sunitinib treatment

$4,6,9-23]$. Only 6 of the 18 reported cases of RCC tongue metastasis presented initially with tongue metastases $[3,4,12,17,18,20]$.

The common clinical presentation includes a rapidly growing mass that often causes hemorrhage [23], as in our case. Other symptoms have been reported, such as dysphagia and dysarthria, which may reflect the mass effect [13].

The main histological subtypes of RCC are clear cell, papillary, chromophobe, collecting duct carcinoma, medullary carcinoma, and unclassified [24]. Unclassified RCC represents approximately 4 to $6 \%$ of all RCCs and are classified as high-grade lesions, characterized by the presence of a sarcomatoid component without any recognized epithelial elements [25]. The sarcomatoid is a tumor differentiation which may coexist with any histologic subtype of RCC [24], and the presence of sarcomatoid elements is associated with an aggressive disease course $[24,26]$. Our patient had a high-grade unclassified RCC with a sarcomatoid component in the biopsy of the tongue lesion.

Treatment alternatives for a tongue metastasis include local excision to relieve symptoms and to provide patient comfort [2]. This palliative surgery is indicated for a rapidly growing metastatic lesion [2]. The introduction of drugs targeting the VEGF pathway or the mTOR pathway has improved the prognosis of RCC [27]. However, an effective systemic therapy for patients with sarcomatoid metastatic RCC has yet to be elucidated [28]. These patients are usually treated with VEGF-targeted therapies, in fewer cases with chemotherapy, or simply referred for supportive care [27]. A retrospective series by Golshayan et al. reported a median overall survival (OS) of 11.8 months and a progression-free survival (PFS) of 5.3 months for patients with sarcomatoid RCC treated with sunitinib [29]. In the series of Molina et al., the median survival of the 29 patients who were treated with sunitinib was 10 months and the PFS was 4.4 months [30]. In the Eastern Cooperative Oncology Group (ECOG) trial 8802, assessing the combination of doxorubicin with gemcitabine in 39 patients with locally advanced or metastatic RCC with sarcomatoid features, the median OS was 8.8 months [28]. With regard to immunotherapy, in a randomized, openlabel phase III study, nivolumab showed a statistically significant improvement in OS compared with everolimus in patients with advanced or metastatic RCC [31]. However, there was not a specific result reported for patients with sarcomatoid component. Geynisman reported one clinical case in which nivolumab led to a rapid response in papillary RCC with sarcomatoid and rhabdoid features [32]. In a phase I study of atezolizumab, an anti-programmed death-ligand 1 antibody, in metastatic RCC with a poor prognosis including sarcomatoid features, the overall response rate (ORR) was 22\%, the median OS was 26.2 months, and the median PFS was 4.2 months [33].

The current case was treated with sunitinib, with a good clinical response after one cycle. Unfortunately, the treatment was discontinued because of an unexplained fever, and the disease progressed. A second-line systemic therapy with doxorubicin and gemcitabine was started, but he died due to a hemorrhagic complication.

\section{Conclusions}

It is important for clinicians to be aware that RCC can lead to lingual metastases. Tongue lesions require a complete assessment to distinguish a metastasis from a primary cancer in order to give the appropriate treatment. 
Table 1 Previous case reports of lingual metastasis from renal cell carcinoma

\begin{tabular}{|c|c|c|c|c|c|}
\hline Author/year & Age/sex & Presentation & Other metastases & Treatment & $\begin{array}{l}\text { Survival } \\
\text { (months) }\end{array}$ \\
\hline Novák et al., 2009 [9] & $63 / F$ & $\begin{array}{l}\text { History of nephrectomy for } \\
\text { RCC } 7 \text { years previously. } \\
\text { Mass on the tongue }\end{array}$ & Not known & Not known & $\begin{array}{l}\text { Not } \\
\text { known }\end{array}$ \\
\hline Altinel et al., 2010 [4] & $67 / \mathrm{M}$ & Tongue lesion & None & $\begin{array}{l}\text { Excision. Nephrectomy. } \\
\text { Interferon-alpha }\end{array}$ & $\begin{array}{l}\text { Not } \\
\text { known } \\
\text { (alive) }\end{array}$ \\
\hline $\begin{array}{l}\text { Wadasadawala et al., } \\
2011 \text { [10] }\end{array}$ & 48/M & $\begin{array}{l}\text { History of nephrectomy and } \\
\text { radiotherapy for RCC. } \\
\text { Dysphagia and dysphonia } \\
\text { and mass on the tongue } \\
5 \text { years later }\end{array}$ & $\begin{array}{l}\text { Adrenals, lungs, } \\
\text { mediastinum, vhbone }\end{array}$ & Radiotherapy & $\begin{array}{l}\text { Not } \\
\text { known } \\
\text { (alive) }\end{array}$ \\
\hline Morvan et al., 2011 [11] & $48 / \mathrm{M}$ & $\begin{array}{l}\text { History of nephrectomy } \\
3 \text { years previously. } \\
\text { Mass on the tongue }\end{array}$ & $\begin{array}{l}\text { Left surrenal, L5 vertebra } \\
\text { and left submandibular } \\
\text { adenopathy }\end{array}$ & $\begin{array}{l}\text { Excision. Radiation } \\
\text { therapy on L5. } \\
\text { Sunitinib }\end{array}$ & 60 (alive) \\
\hline Yoshitomi et al., 2011 [12] & $47 / \mathrm{M}$ & $\begin{array}{l}\text { No history of malignant } \\
\text { disease. } \\
\text { A lump on the tongue }\end{array}$ & Adrenal gland, pleura, lungs & $\begin{array}{l}\text { Nephrectomy. } \\
\text { Excision. } \\
\text { Interferon. } \\
\text { Sunitinib and sorafenib } \\
\text { later }\end{array}$ & 24 (alive) \\
\hline Ghazali et al., 2012 [13] & $64 / F$ & $\begin{array}{l}\text { History of nephrectomy for } \\
\text { RCC } 14 \text { years previously. } \\
\text { Lump on the tongue }\end{array}$ & Contralateral kidney & Excision & 5 \\
\hline Tunio et al., 2012 [14] & $35 / \mathrm{M}$ & $\begin{array}{l}\text { History of nephrectomy } \\
\text { for RCC. } \\
\text { Painless swelling in right } \\
\text { lateral tongue }\end{array}$ & Lung & $\begin{array}{l}\text { Excision. } \\
\text { Radiotherapy. } \\
\text { Intra-oral } \\
\text { electron therapy. } \\
\text { Sunitinib }\end{array}$ & Unknown \\
\hline Novák et al., 2012 [15] & $63 / F$ & $\begin{array}{l}\text { History of nephrectomy } \\
\text { for RCC } 7 \text { years earlier. } \\
\text { Mass on the tongue }\end{array}$ & None & Cryosurgical therapy & 12 \\
\hline Ganini et al., 2012 [16] & 70/M & $\begin{array}{l}\text { History of nephrectomy } \\
\text { for RCC. } \\
16 \text { years later, lesion of the } \\
\text { hemi-tongue }\end{array}$ & $\begin{array}{l}\text { Adrenals, lymph nodes, } \\
\text { lung and bone, skin }\end{array}$ & $\begin{array}{l}\text { Embolization of the } \\
\text { left lingual artery }\end{array}$ & 1 \\
\hline Balliram et al., 2012 [17] & $72 / \mathrm{M}$ & Painless lesion of the tongue & Lung & Nephrectomy & 3 \\
\hline Ray et al., 2013 [3] & $65 / M$ & $\begin{array}{l}\text { Lesion of the tongue with } \\
\text { history of reddish discoloration } \\
\text { of urine }\end{array}$ & $\begin{array}{l}\text { Para-aortic lymphadenopathy, } \\
\text { psoas muscle and right dome } \\
\text { of diaphragm }\end{array}$ & $\begin{array}{l}\text { Excision. } \\
\text { Radiotherapy. } \\
\text { Sunitinib }\end{array}$ & $\begin{array}{l}\text { Not } \\
\text { known }\end{array}$ \\
\hline Mazeron et al., 2013 [18] & $66 / \mathrm{M}$ & Tongue lesion & None & $\begin{array}{l}\text { Nephrectomy. } \\
\text { Sunitinib. } \\
\text { Brachytherapy }\end{array}$ & 41 \\
\hline Matias et al., 2013 [19] & $47 / M$ & $\begin{array}{l}\text { Nephrectomy for RCC, } \\
\text { metastasis } 2 \text { months later. }\end{array}$ & $\begin{array}{l}\text { Lungs, brain, liver, bone, } \\
\text { lymph nodes }\end{array}$ & $\begin{array}{l}\text { Temsirolimus followed } \\
\text { by sunitinib. } \\
\text { Surgical excision } \\
\text { and sorafenib }\end{array}$ & $\begin{array}{l}\text { Not } \\
\text { known }\end{array}$ \\
\hline $\begin{array}{l}\text { Abbaszadeh-Bidokhty et al., } \\
2014 \text { [6] }\end{array}$ & $80 / \mathrm{M}$ & $\begin{array}{l}\text { History of nephrectomy } \\
\text { for RCC } 4 \text { years previously. } \\
\text { Swelling on the tongue }\end{array}$ & None & $\begin{array}{l}\text { Surgical excision. } \\
\text { Sunitinib followed by } \\
\text { sorafenib }\end{array}$ & 6 (alive) \\
\hline Khobragade et al., 2014 [20] & $63 / \mathrm{M}$ & $\begin{array}{l}\text { Swelling over dorsal surface } \\
\text { of tongue with difficulty in } \\
\text { swallowing }\end{array}$ & Lungs & $\begin{array}{l}\text { Nephrectomy. } \\
\text { Excision. } \\
\text { Sunitinib }\end{array}$ & $\begin{array}{l}\text { Not } \\
\text { known }\end{array}$ \\
\hline Altuntaş et al., 2015 [21] & 70/M & Renal mass & Lungs, lymph nodes, bone & $\begin{array}{l}\text { Interferon alpha followed } \\
\text { by partial glossectomy } \\
\text { and sunitinib after } \\
\text { progression }\end{array}$ & 7 (alive) \\
\hline Wang et al., 2016 [22] & $71 / F$ & $\begin{array}{l}\text { History of nephrectomy } \\
10 \text { years previously. } \\
\text { Tumor on the tongue }\end{array}$ & Hilar lymph node, lungs & Sunitinib & 10 (alive) \\
\hline Lieder et al., 2017 [23] & 56/unknown & $\begin{array}{l}\text { Nephrectomy for RCC. } \\
\text { Mass of tongue }\end{array}$ & $\begin{array}{l}\text { Lung, bones, mediastinal } \\
\text { nodes, soft tissue of } \\
\text { the finger }\end{array}$ & Excision radiotherapy & 3 \\
\hline
\end{tabular}




\section{Abbreviations}

CT: Computed tomography; mTOR: Mammalian target of rapamycin; OS: Overall survival; PET-CT: Positron-emission tomographic-computed tomography; PFS: Progression-free survival; RCC: Renal cell carcinoma; VEGF: Vascular endothelial growth factor

\section{Acknowledgements}

We would like to thank PRS for proofreading of this manuscript.

\section{Funding}

No funds were received in support of this work.

\section{Availability of data and materials}

All data generated or analyzed during this study are included in this published article.

\section{Authors' contributions}

HR performed literature review, composed this case report, and wrote the manuscript. SD was involved in the data collection. ML helped in the literature research. ST and HE corrected and approved the final version of the manuscript. All authors read and approved the final manuscript.

\section{Ethics approval and consent to participate}

Not applicable.

\section{Consent for publication}

Written informed consent was obtained from the patient for publication of this case report and any accompanying images. A copy of the written consent is available for review by the Editor-in-Chief of this journal.

\section{Competing interests}

The authors declare that they have no competing interests.

\section{Publisher's Note}

Springer Nature remains neutral with regard to jurisdictional claims in published maps and institutional affiliations.

\section{Author details}

'Service d'Oncologie Médicale, Institut National d'Oncologie, CHU Rabat and Université Mohamed V, Avenue Allal Al Fassi, Madinat Al Irfane, 10000 Rabat, Morocco. ${ }^{2}$ Institut de Cancérologie, Hospices Civils de Lyon and Université de Lyon, 165, Chemin du Grand Revoyet, 69495 Pierre-Bénite cedex, France.

Received: 2 January 2017 Accepted: 20 September 2017

Published online: 07 November 2017

\section{References}

1. Tas F, Karabulut S, Yegen G, Onder S, Ciftci R. Tongue metastasis of melanoma. J Cancer Res Ther. 2015;11(3):660.

2. Torres-Carranza E, Garcia-Perla A, Infante-Cossio P, Belmonte-Caro R, Loizaga-Iriondo JM, Gutierrez-Perez JL. Airway obstruction due to metastatic renal cell carcinoma to the tongue. Oral Surg Oral Med Oral Pathol Oral Radiol Endod. 2006;101(3):e76-8.

3. Ray A, Bhattacharya J, Ganguly S. Renal cell carcinoma presenting with oral tongue metastasis: a rare case presentation. J Cancer Res Ther. 2013;9(1): $117-8$.

4. Altinel D, Etıt D, Tan A, Bayol U, Bulut V, Erdoğan IG, et al. Metastatic renal cell carcinoma initially presented as a tongue mass. Turk J Pathol. 2010;26: 261-3.

5. Azam F, Abubakerr M, Gollins S. Tongue metastasis as an initial presentation of renal cell carcinoma: a case report and literature review. J Med Case Rep. 2008;2:249.

6. Abbaszadeh-Bidokhty H, Motallebnejad M, Rajabi-Moghaddam M. Metastatic Renal cell Carcinoma Presenting as a clear-cell Tumor in Tongue: A Case Report. Iran J Otorhinolaryngol. 2014;26(76):185-90.

7. Zarrabi K, Fang C, Wu S. New treatment options for metastatic renal cell carcinoma with prior anti-angiogenesis therapy. J Hematol Oncol. 2017; 10(1):38.

8. Miller K, Bergmann L, Doehn C, Gschwend J, Keilholz U. Interdisciplinary Recommendations for the Treatment of Metastatic Renal Cell Carcinoma. Aktuelle Urol. 2017;48(1):72-8.
9. Novák P, Németh I, Hamar S, Tiszlavicz L, Szalai L, Sonkodi I, Nagy K. Clear cell adenocarcinoma of the tongue. Coincidence or distant metastasis? Fogorv Sz. 2009;102(5):183-6.

10. Wadasadawala T, Kumar P, Agarwal J, Ghosh-Laskar S. Palliation of dysphagia with radiotherapy for exophytic base tongue metastases in a case of renal cell carcinoma. Indian J Urol. 2011;27(4):550-2.

11. Morvan JB, Veyrières JB, Mimouni $O$, Cathelinaud $O$, Allali L, Verdalle $P$. Clear-cell renal carcinoma metastasis to the base of the tongue and sphenoid sinus: Two very rare atypical ENT locations. Eur Ann Otorhinolaryngol Head Neck Dis. 2011;128(2):91-4.

12. Yoshitomi I, Kawasaki G, Mizuno A, Nishikido M, Hayashi T, Fujita S, Ikeda T. Lingual metastasis as an initial presentation of renal cell carcinoma. Med Oncol. 2011;28(4):1389-94.

13. Ghazali N, Davis C, Barrett AW, Tighe JV. Bilateral asynchronous renal cell carcinoma with metastatic involvement of the tongue. Case Rep Pathol. 2012;2012:729642. Epub 2012 Sep 12.

14. Tunio MA, AlAsiri M, Ahmad S, Fareed M, Bayoumi Y. Tongue metastasis as an initial manifestation of metastasis in renal cell carcinoma: A case report. J Solid Tumors. 2012;2(2):39-42.

15. Novak P, Sükösd F, Hamar S, Nemeth I, Tiszlavicz L, Szalay I, Sonkodi I, Ivanyi B, Nagy K. Metachronous clear cell carcinoma of the tonque and kidney: a diagnostically challenging coincidence. Oral Surg Oral Med Oral Pathol Oral Radiol. 2012;114(4):e25-30.

16. Ganini C, Lasagna A, Ferraris E, Gatti P, Paglino C, Imarisio I, Morbini P, Benazzo M, Porta C. Lingual metastasis from renal cell carcinoma: a case report and literature review. Rare Tumors. 2012;4(3):e41.

17. Balliram S, Goetz L, Ramsoobhag K, Narinesingh D, Medford S, Naraynsingh V. Renal cell carcinoma presenting as a tongue lesion. J Oral Maxillofac Surg. 2012;70(7):1605-8.

18. Mazeron R, Fenoll L, Mathieu MC, Dumas I, Haie-Meder C. Brachytherapy for isolated tongue metastasis of renal clear cell carcinoma. Eur Ann Otorhinolaryngol Head Neck Dis. 2013;130(3):149-51.

19. Matias M, Casa-Nova M, Borges-Costa J, Ribeiro L. Unusual head metastasis of kidney cancer. BMJ Case Rep. 2013;10:2013. doi:10.1136/bcr-2013-200004.

20. Khobragade KH, Bakshi GK, Prakash G, Menon S. Tongue trail to kidney. Indian J Med Paediatr Oncol. 2014;35(1):106-8.

21. Altuntaş O, Petekkaya I, Süslü N, Güllü I. Renal cell carcinoma metastatic to the tongue: a case report and review of the literature. J Oral Maxillofac Surg. 2015;73(6):1227-30.

22. Wang C, Takeda K, Shiba M, Takayama H, Munakata S. Metastasis to the Tongue from Renal Cell Carcinoma 10 Years after Nephrectomy : A Case Report. Hinyokika Kiyo. 2016;62(8):407-10.

23. Lieder A, Guenzel T, Lebentrau S, Schneider C, Franzen A. Diagnostic relevance of metastatic renal cell carcinoma in the head and neck: An evaluation of 22 cases in 671 patients. Int Braz J Urol. 2017;43(2):202-8.

24. Ishigami T, Uzawa K, Kasamatsu A, Usukura K, Koyama T, Kouzu Y, Koike H, Sakamoto Y, Ogawara K, Shiiba M, Yokoe H, Akiba M, Tanzawa H. A case of metastatic sarcomatoid renal cell carcinoma diagnosed by trismus as the initial symptom. J Oral Maxillofac Surg Med Pathol. 2014;26:492-6.

25. Muglia VF, Prando A. Renal cell carcinoma: histological classification and correlation with imaging findings. Radiol Bras. 2015;48(3):166-74.

26. Adibi M, Thomas AZ, Borregales LD, Merrill MM, Slack RS, Chen H, Sircar K, Murugan P, Tamboli P, Jonasch E, Tannir NM, Matin SF, Wood CG, Karam AJ. Percentage of sarcomatoid component as a prognostic indicator for survival in renal cell carcinoma with sarcomatoid dedifferentiation. Urol Oncol. 2015; 33:427. e17-23.

27. Kunene V, Miscoria M, Pirrie S, Islam MR, Afshar M, Porfiri E. Sarcomatoid renal cell carcinoma: clinical outcome and survival after treatment with sunitinib. Clin Genitourin Cancer. 2014;12(4):251-5.

28. Pal SK, Jones JO, Carmichael C, Saikia J, Hsu J, Liu X, Figlin RA, Twardowski $P$, Lau C. Clinical outcome in patients receiving systemic therapy for metastatic sarcomatoid renal cell carcinoma: a retrospective analysis. Urol Oncol. 2013;31(8):1826-31.

29. Golshayan AR, George S, Heng DY, Elson P, Wood LS, Mekhail TM, Garcia JA, Aydin H, Zhou M, Bukowski RM, Rini Bl. Metastatic sarcomatoid renal cell carcinoma treated with vascular endothelial growth factor-targeted therapy. J Clin Oncol. 2009;27(2):235-41.

30. Molina AM, Tickoo SK, Ishill N, Trinos MJ, Schwartz LH, Patil S, Feldman DR, Reuter VE, Russo P, Motzer RJ. Sarcomatoid-variant renal cell carcinoma: treatment outcome and survival in advanced disease. Am J Clin Oncol. 2011;34(5):454-9. 
31. Motzer RJ, Escudier B, McDermott DF, George S, Hammers HJ, Srinivas S, Tykodi SS, Sosman JA, Procopio G, Plimack ER, Castellano D, Choueiri TK, Gurney H, Donskov F, Bono P, Wagstaff J, Gauler TC, Ueda T, Tomita Y, Schutz FA, Kollmannsberger C, Larkin J, Ravaud A, Simon JS, Xu LA, Waxman IM, Sharma P. CheckMate 025 Investigators. Nivolumab versus Everolimus in Advanced Renal-Cell Carcinoma. N Engl J Med. 2015;373(19):1803-13.

32. Geynisman DM. Anti-programmed Cell Death Protein 1 (PD-1) Antibody Nivolumab Leads to a Dramatic and Rapid Response in Papillary Renal Cell Carcinoma with Sarcomatoid and Rhabdoid Features. Eur Urol. 2015;68(5): 912-4.

33. McDermott DF, Sosman JA, Sznol M, Massard C, Gordon MS, Hamid O, Powderly JD, Infante JR, Fassò M, Wang W, Zou W, Hegde PS, Fine GD, Powles T. Atezolizumab, an Anti-Programmed Death-Ligand 1 Antibody, in Metastatic Renal Cell Carcinoma: Long-Term Safety, Clinical Activity, and Immune Correlates From a Phase la Study. J Clin Oncol. 2016;34(8):833-42.

\section{Submit your next manuscript to BioMed Central} and we will help you at every step:

- We accept pre-submission inquiries

- Our selector tool helps you to find the most relevant journal

- We provide round the clock customer support

- Convenient online submission

- Thorough peer review

- Inclusion in PubMed and all major indexing services

- Maximum visibility for your research

Submit your manuscript at www.biomedcentral.com/submit 